\title{
Predicted effect of ore composition on slag formation in manganese ore reduction
}

\author{
Theresa Coetsee*1 ${ }^{* 1}$ Johan Zietsman ${ }^{2}$ and Chris Pistorius ${ }^{3}$
}

\begin{abstract}
Previous work showed that manganese ore reduction rates are strongly influenced by the extent of slag phase formation. In this work, the effect of ore composition on slag formation during manganese oxide reduction was predicted using thermochemical calculations; FactSage $6 \cdot 4$ was used to calculate the equilibrium phase relations in the oxide system $\mathrm{MnO}-\mathrm{SiO}_{2}-\mathrm{CaO}-\mathrm{MgO}-$ $\mathrm{Al}_{2} \mathrm{O}_{3}$. Practically observed differences in ore composition, even within the same orebody, are predicted to cause significant differences in slag formation during reduction, with large differences in ore reducibility expected.
\end{abstract}

Keywords: Manganese, Thermochemical modelling, Monoxide, Slag, Reduction

\section{Introduction}

This paper considers predicted effects of changes in phase composition, specifically slag formation, in the production of high-carbon ferromanganese. As background to the calculated changes in slag proportion during reduction of manganiferous ores, relevant process characteristics, temperatures and reactions steps are briefly reviewed:

The Submerged Arc Furnace (SAF) process is most widely used in the industrial production of high carbon ferromanganese. This process requires lump ore and reductant of $6-75 \mathrm{~mm}$ as feed material to ensure sufficient gas permeability through the material bed, (Habashi, 1997). Normal slag tapping temperatures from the SAF have been reported at $1450-1500^{\circ} \mathrm{C}$, (Olsen et al., 2007). In the coke bed of the SAF, where final reduction of $\mathrm{MnO}$ takes place, temperatures would be well in excess of the reported slag tapping temperatures.

In the SAF ore fines can only be used as feed in the form of sinter that is prepared in a separate process reactor (sinter strand). Other processing alternatives to the SAF have been developed to enable the use of manganese ore fines $(-10 \mathrm{~mm}$ particle size $)$ directly as feed material, and of ultra-fine ore $(-212 \mu \mathrm{m}$ particle size) with reductant in the form of self-reducing agglomerates. One such process is described in US patent 6146437 (Fourie, 2000) in which ore and coal fines of $-10 \mathrm{~mm}$ are used as feed materials. The raw material mix is fed onto a liquid alloy bath, forming heaps of reacted material. The heap material is heated at the heap top surface by heat generated from burning combustibles with oxygen enriched air. The combustibles consist of natural gas, coal volatiles, coal carbon and reduction

\footnotetext{
${ }^{1}$ Exxaro Resources, Pretoria, South Africa

${ }^{2}$ University of Pretoria, Pretoria, South Africa

${ }^{3}$ Carnegie Mellon University, Pittsburgh, PA, USA

*Corresponding author, email theresa.coetsee@exxaro.com
}

reaction product gas emanating from the heaps. Final reaction and smelting of the heap material supported by energy transferred from the induction-heated metal bath. The material mixture is reacted at temperatures of 1400 $1550^{\circ} \mathrm{C}$.

Utilisation of ultra-fine ore and reductant in the form of self-reducing pellets has been reported by Braga et al. (2007). Reduction occurs quickly inside the pellet at temperatures of $1250-1400^{\circ} \mathrm{C}$, before bulk melting of the pellet occurs. The chemical composition of composite pellets can be manipulated readily, facilitated by the small particle sizes and close contact of ore and reductant.

Various particles size ranges and associated reaction temperatures are therefore applicable to ferromanganese production. Final reduction of $\mathrm{MnO}$ takes place at different temperatures in the various process configurations: mixed lump ore and reductant at temperatures in excess of $1500^{\circ} \mathrm{C}$ in the SAF, mixed ore and reductant fines of $-10 \mathrm{~mm}$ at temperatures of $1400-1550^{\circ} \mathrm{C}$ in the process described in US patent 6146437, and mixed ore and reductant ultra fines of $-212 \mu \mathrm{m}$ at temperatures of $1250-1400^{\circ} \mathrm{C}$ in pellets.

Manganese ores are highly heterogeneous and contain various minerals with different levels of manganese content. For example, Koursaris et al. (1983) reported significant variations in the proportions of manganese containing minerals and gangue minerals between ore particles, and between areas within the same ore particle for Mamatwan ore. Reduced manganese ore particles therefore seldom display homogeneous reduction. For example, for Wessels ore reacted with graphite under hydrogen at $1200^{\circ} \mathrm{C}$ (isothermally), a small proportion of ore particles was reduced to approximately $30 \%$ reduction level while the overall degree of reduction was $80 \%$ (Kononov et al., 2009). It is important to note that the equilibrium calculation results presented here cannot account for this heterogeneity, but rather describe the averaged reduction behaviour of bulk ore. 


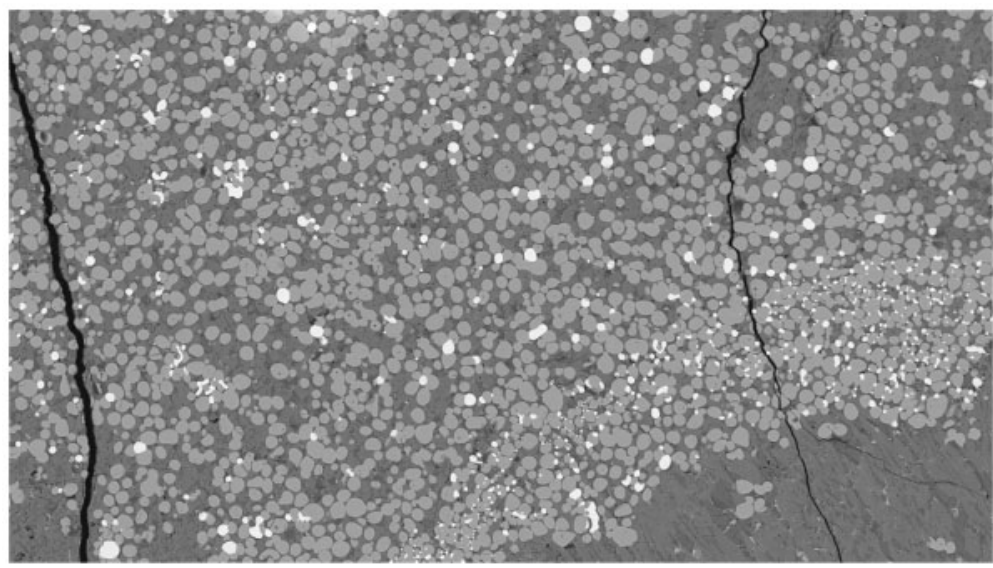

1 Typical phase assemblage for Mno reduction from manganese ore. (White phase=alloy; rounded grey phase=monoxide; grey background=slag; field of view $=1.3 \mathrm{~mm}$; backscattered electron image)

Studies on the reduction behaviour of manganese ores have identified two to three distinctive reduction stages (Eric and Burucu, 1992; Ostrovski and Webb, 1995; Ostrovski et al., 2004). In the second and third reduction stages manganese is reduced from the liquid slag phase and from the monoxide solid-solution phase, if the latter is present. In ore of negligible $\mathrm{MgO}$ content the monoxide phase contains mostly $\mathrm{MnO}$ and the $\mathrm{MnO}$ activity in the monoxide is close to unity. Once manganese reduction has proceeded to the extent that the monoxide is consumed, and only dissolved $\mathrm{MnO}$ in the liquid slag phase remains, the reduction reaction slows dramatically as the $\mathrm{MnO}$ activity decreases, (Tangstad and Olsen, 1997). Therefore, the slag-forming behaviour of the ore would determine the temperature and reduction range within which $\mathrm{MnO}$ reduction would be fast. It is expected that fast reduction would cease once high $\mathrm{MnO}$ containing monoxide has disappeared.

Experimental measurement of the ore softening and melting temperatures, as affected by the extent of reduction, requires extensive physical test work. However, the expected melting behaviour of different ores can be compared quickly by using thermochemical modelling software such as FactSage. The objective of this paper is to show, using thermochemical calculations, the effect of different ore chemical compositions on the melting behaviour of manganese ores, and the expected implications for ore reduction behaviour in the second and third reduction stages for reduction of $\mathrm{MnO}$ to alloy.

\section{Previous work}

Several experimental test series have been conducted in the past in order to study the reduction behaviour of different manganese ores.

\section{Table 1 Manganese ore reduction stages}

\begin{tabular}{ll}
\hline Reduction stage & Chemical reactions \\
\hline 1 & $<\mathrm{Fe}_{2} \mathrm{O}_{3}>+[\mathrm{CO}] \rightarrow 2<\mathrm{FeO}>+\left[\mathrm{CO}_{2}\right]$ \\
& $<\mathrm{Mn}_{2} \mathrm{O}_{3}>+[\mathrm{CO}] \rightarrow<\mathrm{MnO}>+\left[\mathrm{CO}_{2}\right]$ \\
2 & $<\mathrm{FeO}>+[\mathrm{CO}] \rightarrow<\mathrm{Fe}>+\left[\mathrm{CO}_{2}\right]$ \\
& $<\mathrm{MnO}>+(\mathrm{C})_{\mathrm{m}} \rightarrow(\mathrm{Mn})_{\mathrm{m}}+[\mathrm{CO}]$ \\
3 & $<\mathrm{MnO}>+(\mathrm{C})_{\mathrm{m}} \rightarrow(\mathrm{Mn})_{\mathrm{m}}+[\mathrm{CO}]$ \\
\hline
\end{tabular}

\langle\rangle$=$ solid; []$=$ gas; ()$=$ liquid $;()_{\mathrm{m}}=$ dissolved in alloy.
Three reaction stages were identified by Eric and Burucu (1992) during the reduction of Mamatwan ore of $-300 \mu \mathrm{m}$ with graphite of $-43 \mu \mathrm{m}$ at $1250-1350^{\circ} \mathrm{C}$, and only two reaction stages at $1100-1200^{\circ} \mathrm{C}$. The reduction stages are summarised in Table 1 .

The rapid first stage results in the reduction, by $\mathrm{CO}$, of higher oxides of manganese and iron to $\mathrm{MnO}$ and $\mathrm{FeO}$ (resulting in approximately $30 \%$ reduction). In the markedly slower second stage of reduction metallisation of $\mathrm{FeO}$ and $\mathrm{MnO}$ starts. Metallisation begins with metallic iron nucleation throughout the reduced ore particle, next to solid monoxide particles within the liquid silicate slag. Figure 1 shows a backscattered electron image of the typical phase assemblage for this reduction stage. As manganese reduction progresses the iron nuclei are alloyed with manganese and carbon. The alloy phase is usually reported as a solid phase of specific stoichiometry as identified in subsequent XRD analysis, such as $(\mathrm{Mn}, \mathrm{Fe})_{5} \mathrm{C}_{2}$, but at the reaction temperatures, typically above $1300^{\circ} \mathrm{C}$, the alloy is liquid or a mixture of solid and liquid (Koursaris and See, 1979; Akdogan and Eric, 1995). Eric and Burucu (1992) determined that the second reduction stage spanned the reduction range of $30-60 \%$ at $1300^{\circ} \mathrm{C}$ and $30-70 \%$ at $1350^{\circ} \mathrm{C}$, for Mamatwan ore reduction

In the third stage, the final reduction of $\mathrm{MnO}$ by carbon dissolved in alloy phase occurs at the solid monoxide-alloy phase interface. This stage has the lowest reduction rate (Eric and Burucu, 1992), most likely due to the slow diffusion of $\mathrm{Mn}^{2+}$ ions in the monoxide phase, and/or liquid slag phase coating the monoxide phase. The important kinetic effect of the formation of the liquid slag phase was illustrated clearly by comparison of reduction of pure $\mathrm{Mn}_{3} \mathrm{O}_{4}$ and ore under the same conditions: initially the ore reacted much faster than $\mathrm{Mn}_{3} \mathrm{O}_{4}$, (attributed to catalysis of reduction by $\mathrm{Fe}_{2} \mathrm{O}_{3}$ in the ore). Then, as the reduction process progressed, the reduction rate of $\mathrm{Mn}_{3} \mathrm{O}_{4}$ surpassed the reduction rate of the ore at $68 \%$ reduction at $1350^{\circ} \mathrm{C}$, and at $64 \%$ reduction at $1300^{\circ} \mathrm{C}$, associated with the formation of liquid slag in the ore, covering the monoxide phase and slowing reduction.

Several studies on different ores and pure $\mathrm{MnO}$ with silica additions have reported the same effect. Van Deventer (1987) showed that the reduction of $\mathrm{MnO}$ with graphite at $1350{ }^{\circ} \mathrm{C}$ slowed when as little as $2 \cdot 5 \% \mathrm{SiO}_{2}$ 
was added; the slower reduction was attributed to formation of beta- $\mathrm{MnSiO}_{3}$ covering the $\mathrm{MnO}$ particles (so reducing the contact area between the $\mathrm{MnO}$ grains and the reducing atmosphere) and/or a decrease in the activity of $\mathrm{MnO}$ due to manganese-silicate slag phase formation.

Ostrovski and Webb (1995) studied the reduction of siliceous Groote Eylandt ore with graphite at 900, 1200 and $1400^{\circ} \mathrm{C}$; the calculated diffusion coefficient of $\mathrm{MnO}$ in the liquid slag phase at $1400^{\circ} \mathrm{C}$ was smaller than that reported by Eric and Burucu (1992) for Mamatwan ore. The lower diffusivity and slower reduction of the siliceous ore were attributed to the higher silica content of this ore (Ostrovski and Webb, 1995).

Akdogan and Eric (1995) identified liquid silicate phase formation already at $1200^{\circ} \mathrm{C}$ for Wessels ore; the liquid phase was calcium-manganese-silicate initially, changing to calcium-silicate as reduction of $\mathrm{MnO}$ proceeded. In comparison, the rate and extent of reduction of $\mathrm{MnO}$ to ferromanganese alloy in sintered Groote Eylandt ore was slower (Ostrovski et al., 2004), associated with formation of liquid slag in Groote Eylandt ore at $1100^{\circ} \mathrm{C}$ and above. The liquid slag phase limits access of the reducing gas to the ore particle interior and retards reduction. Lime doping of the Groote Eylandt ore resulted in significant increases in reduction rate as compared with both Wessels and Groote Eylandt ore without $\mathrm{CaO}$ addition. The authors explained that the effect of $10 \% \mathrm{CaO}$ addition to Groote Eylandt ore increased the melting point of the liquid slag phase preventing liquid silicate formation at experimental temperatures.

It is clear from these previous studies on different ore types that the formation of liquid silicate in the reduced ore particle is associated with retardation of $\mathrm{MnO}$ reduction, in contrast with production of iron in bath smelters, where the slag phase supports rapid reduction of iron oxide. The rate-limiting effect of liquid slag formation in $\mathrm{MnO}$ reduction was also confirmed by work on reaction of composite pellets (consisting of manganese ore and coal), at a temperature of $1600^{\circ} \mathrm{C}$ : slag formation was found to be associated with slower reduction, and pellets that formed more slag (higherbasicity pellets) were found to give significantly lower reduction rates (Peretyagin and Pavlov, 2003).

Knowledge of the extent of liquid silicate formation (with increasing temperature and degree of reduction) is thus expected to be useful in the prediction of ore reduction rate. Prediction of liquid formation would be useful in designing ore blend ratios when ore and/or sinter are used. The use of agglomerates in a manganese production process allows the flexibility to manipulate the ore chemical composition to limit the formation of the liquid slag phase at low temperatures to ensure increased $\mathrm{MnO}$ reduction rates. This is in contrast with the situation in which lump ore or larger ore fines are used, where only the composition of the liquid slag phase formed upon bulk melting of the total furnace feed can be manipulated. As shown by Braga et al. (2007) the use of composite pellets at $1400^{\circ} \mathrm{C}$ allows fast reduction of $\mathrm{MnO}$ to ferromanganese alloy before bulk melting of the agglomerate occurs which then results in a lower reduction rate.

Liquid silicate phase formation is also expected to limit carbon transfer to the metallic iron nuclei (formed in the second reduction stage). The initial metal nuclei, formed throughout the reduced ore particle, contain no carbon. With increased reduction of $\mathrm{MnO}$ the metal nuclei grow in volume and increase in manganese and carbon content. Carbon dissolved in the metal prills plays an important role in the reduction of $\mathrm{MnO}$ in the second reduction stage (Akdogan and Eric, 1995). The carburisation of the metal particles in the reduced ore particles can occur via the reverse Boudouard reaction (Koursaris et al., 1983). Therefore, access of gaseous species is required for metallic iron nuclei formation from $\mathrm{FeO}$ reduction and for carburisation of the metal phase in the interior of the reduced ore particle.

Slag formation also affects electrical behaviour. In the SAF the electric resistance of the furnace charge determines operational stability. The specific conductivity of the ore relative to that of the coke in the mixed burden increases with increasing temperature as the ore softens and melts because the contact area with the electrode increases and also because the ore becomes an ionic conductor as it melts (Miyauchi et al., 2001). Thus, the melting behaviour of the ore is also important for efficient energy input into the ore-coke charge, with ores melting at lower temperature and forming larger quantities of liquid silicate phase being detrimental to stable furnace operation (Miyauchi et al., 2001).

Based on all these considerations, late or limited formation of liquid silicate (slag) during $\mathrm{MnO}$ reduction would be preferred. Calculated differences in slag formation during reduction of different ores and mixtures are presented below.

\section{Input data}

\section{Ore chemical composition}

Table 2 shows the bulk chemical composition of three ores, all South African in origin, used as input to the calculations. Ore1 and Ore2 originate from the same mine, and have similar manganese and iron contents, but different proportions of gangue, specifically quite different ratios of $\mathrm{CaO}$ and $\mathrm{SiO}_{2}$. The equilibrium calculations (presented below) show different product phase proportions. The mass percentages in Table 2 do not add up to $100 \%$ because manganese and iron are reported as $\mathrm{MnO}$ and $\mathrm{FeO}$, rather than the actual higher oxidation states in the ores.

The oxide system was simplified to the main components of $\mathrm{MnO}-\mathrm{SiO}_{2}-\mathrm{CaO}-\mathrm{MgO}-\mathrm{Al}_{2} \mathrm{O}_{3}$ which remain as oxides during the slow second stage of reduction (when $\mathrm{MnO}$ is reduced to alloy). In Fig. 2, it is seen that the manganese content in the oxides remaining after partial reduction is the same for Ore1 and Ore2 at each level of manganese reduction. Therefore, whether Ore 1 or Ore 2 is used in combination with Ore3, the result is the same manganese oxide percentage in the ore mixture at each level of manganese reduction. Two mixtures were tested: Mix1 which contains $44 \%$ Ore 3 and $56 \%$ Ore 1 and Mix 2 which contains $44 \%$ Ore 3 and $56 \%$ Ore 2.

\section{Equilibrium calculations}

Phase equilibrium data is known for the lower-order systems in the system $\mathrm{MnO}-\mathrm{SiO}_{2}-\mathrm{CaO}-\mathrm{MgO}-\mathrm{Al}_{2} \mathrm{O}_{3}$, but not for the multi-component system itself. FactSage allows the prediction of the complex thermochemical equilibrium to evaluate the melting behaviour of the oxide mixture as a function of reaction extent. The 


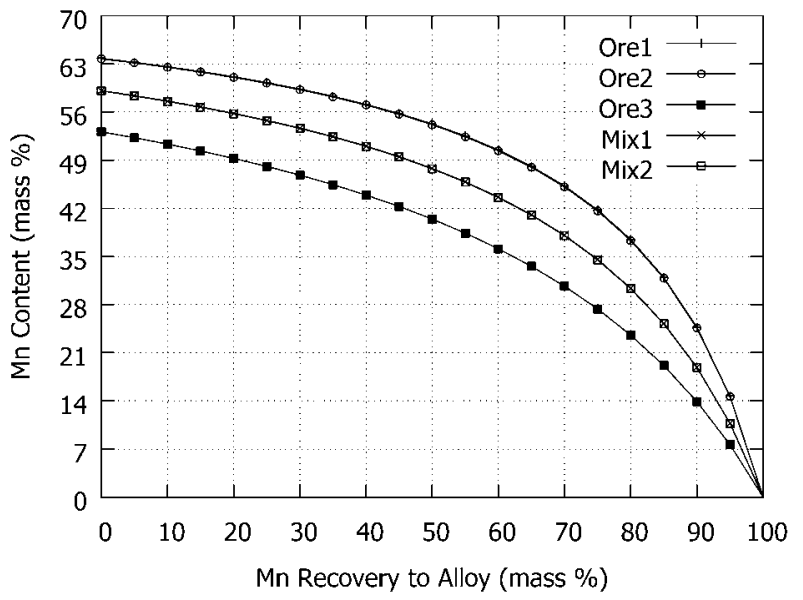

2 Reduced ore manganese content as a function of manganese reduction for ores and ore mixtures

equilibrium module in FactSage 6.4 was used to calculate the equilibrium phase relations in the oxide system $\mathrm{MnO}-\mathrm{SiO}_{2}-\mathrm{CaO}-\mathrm{MgO}-\mathrm{Al}_{2} \mathrm{O}_{3}$; the FToxid database was used in all calculations. The simplified fivecomponent compositions from Table 2 were used as the starting composition at $0 \% \mathrm{MnO}$ reduction. The oxide composition changes upon $\mathrm{MnO}$ reduction were calculated with a simple mass balance, and these composition values were used as input value sets to equilibrium calculations. It was assumed that only $\mathrm{MnO}$ is removed from the oxide system during reduction, and that all the other oxides $\left(\mathrm{SiO}_{2}, \mathrm{CaO}, \mathrm{MgO}\right.$ and $\left.\mathrm{Al}_{2} \mathrm{O}_{3}\right)$ remain unreacted. Calculations were made for temperatures of $1300-1500^{\circ} \mathrm{C}$ and atmospheric pressure value set to $1 \mathrm{~atm}$.

Table 2 Bulk chemical composition of ores (mass percentages)

Ore composition

\begin{tabular}{|c|c|c|c|}
\hline & Ore1 & Ore2 & Ore3 \\
\hline $\mathrm{SiO}_{2}$ & 5.09 & $7 \cdot 49$ & $5 \cdot 61$ \\
\hline $\mathrm{Al}_{2} \mathrm{O}_{3}$ & 0.30 & 0.32 & 0.19 \\
\hline $\mathrm{FeO}$ & $14 \cdot 15$ & $13 \cdot 40$ & $6 \cdot 61$ \\
\hline $\mathrm{TiO}_{2}$ & 0.02 & 0.02 & 0.01 \\
\hline $\mathrm{CaO}$ & $6 \cdot 61$ & $4 \cdot 88$ & $12 \cdot 9$ \\
\hline $\mathrm{MgO}$ & 0.89 & 0.83 & $3 \cdot 82$ \\
\hline $\mathrm{K}_{2} \mathrm{O}$ & 0.04 & 0.00 & 0.00 \\
\hline $\mathrm{MnO}$ & $60 \cdot 31$ & $62 \cdot 80$ & $49 \cdot 20$ \\
\hline $\mathrm{P}$ & 0.02 & 0.02 & 0.01 \\
\hline S & $0 \cdot 15$ & $0 \cdot 15$ & 0.03 \\
\hline $\mathrm{Ba}$ & 0.44 & 0.45 & $0 \cdot 12$ \\
\hline $\mathrm{Na}_{2} \mathrm{O}$ & $0 \cdot 13$ & 0.02 & 0.02 \\
\hline Moisture & 0.87 & 0.98 & 0.05 \\
\hline Total & $89 \cdot 0$ & $91 \cdot 4$ & $78 \cdot 6$ \\
\hline $\mathrm{B} 2=\% \mathrm{CaO} / \% \mathrm{SiO}_{2}$ & $1 \cdot 30$ & 0.65 & $2 \cdot 30$ \\
\hline $\mathrm{B} 3=(\% \mathrm{CaO}+\% \mathrm{MgO}) / \% \mathrm{SiO}_{2}$ & $1 \cdot 47$ & $0 \cdot 76$ & $2 \cdot 98$ \\
\hline $\mathrm{Mn} / \mathrm{Fe}$ & $4 \cdot 2$ & $4 \cdot 7$ & $7 \cdot 4$ \\
\hline \multicolumn{4}{|c|}{$\begin{array}{l}\text { Ore composition used as input in FactSage calculations at zero } \\
\text { MnO reduction level }\end{array}$} \\
\hline $\mathrm{SiO}_{2}$ & $7 \cdot 0$ & $9 \cdot 8$ & $7 \cdot 8$ \\
\hline $\mathrm{Al}_{2} \mathrm{O}_{3}$ & $0 \cdot 4$ & $0 \cdot 4$ & 0.3 \\
\hline $\mathrm{CaO}$ & $9 \cdot 0$ & $6 \cdot 4$ & $18 \cdot 0$ \\
\hline $\mathrm{MgO}$ & $1 \cdot 2$ & $1 \cdot 1$ & $5 \cdot 3$ \\
\hline $\mathrm{MnO}$ & $82 \cdot 4$ & $82 \cdot 3$ & $68 \cdot 6$ \\
\hline Total & $100 \cdot 0$ & $100 \cdot 0$ & $100 \cdot 0$ \\
\hline
\end{tabular}

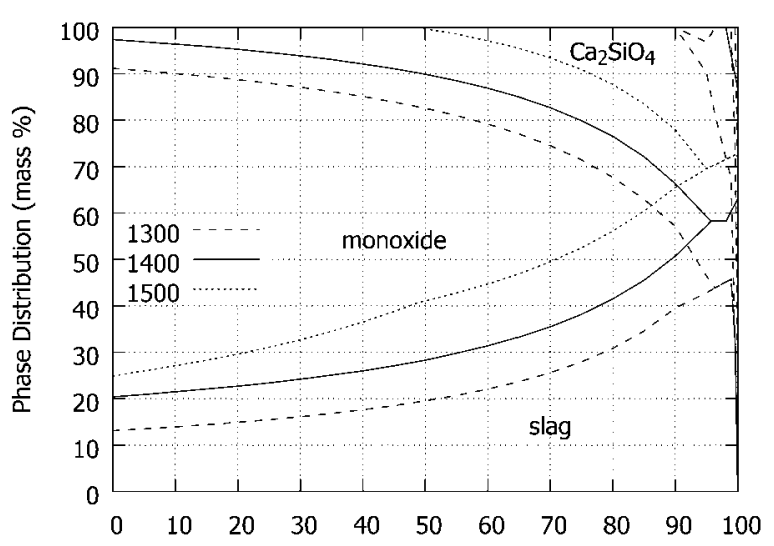

(a)

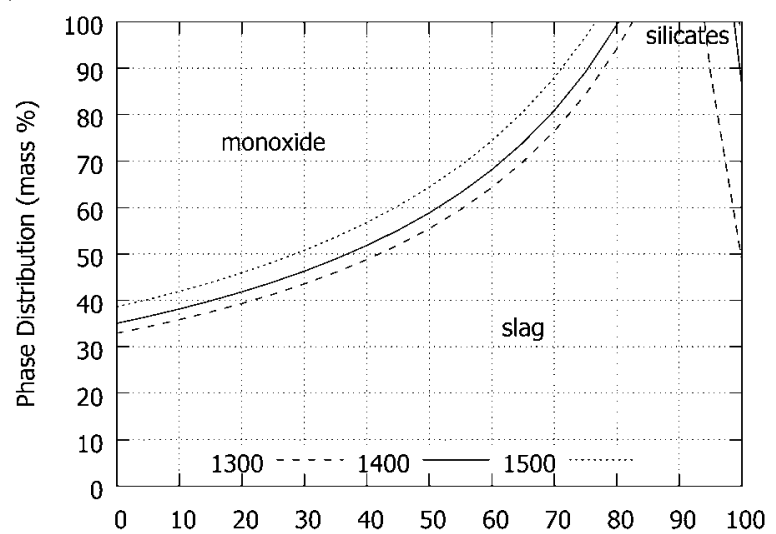

(b)

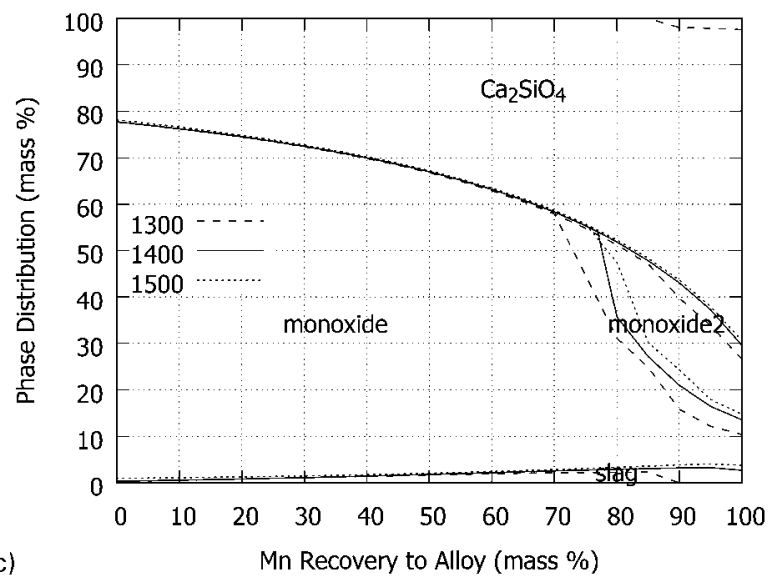

3 Ore phase distribution as a function of manganese recovery to alloy. $a$ Ore1, $b$ Ore2, $c$ Ore3

\section{Results and discussion}

The calculated equilibrium phases for the three ore compositions (listed in Table 2) for temperatures of $1300-1500^{\circ} \mathrm{C}$ are shown in Fig. $3 a-c$. The calculated manganese distribution between the phases remaining in the reduced ore is shown in Fig. $4 a-c$. Within Orel increasing proportions of liquid silicate slag and solid dicalcium silicate are formed as $\mathrm{MnO}$ reduction proceeds, while the proportion of monoxide solid solution phase decreases as the $\mathrm{MnO}$ is reduced. The bulk of the manganese is contained within the monoxide phase. Within Ore2 only slag and monoxide are present throughout the $\mathrm{MnO}$ reduction progression. Initially the bulk of the manganese is contained in the monoxide phase, but with increased $\mathrm{MnO}$ reduction extent this phase is 


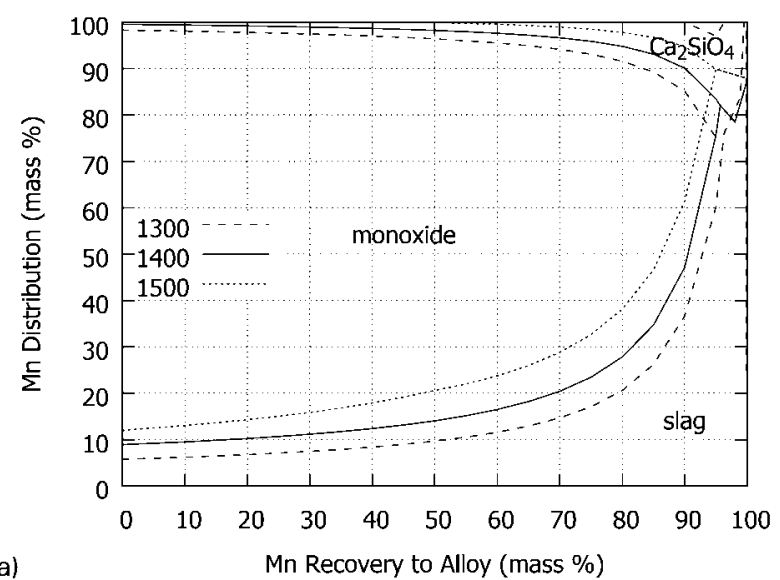

(a)

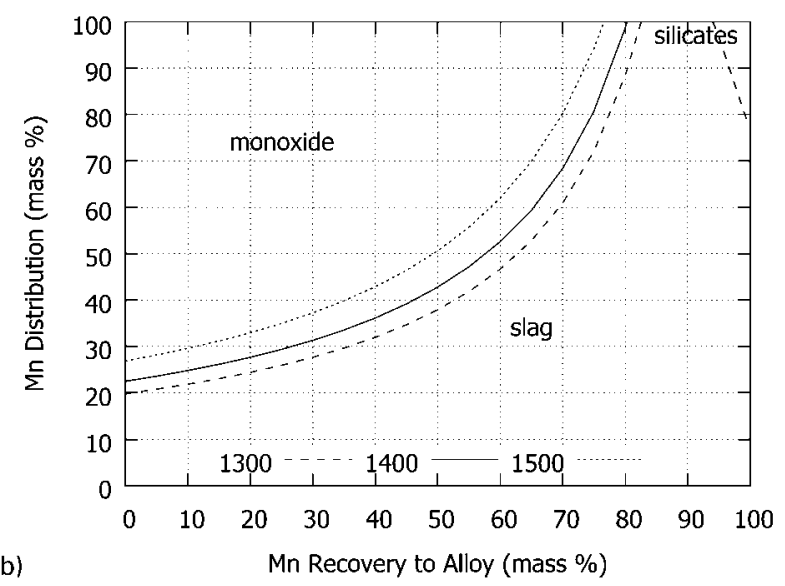

(b)

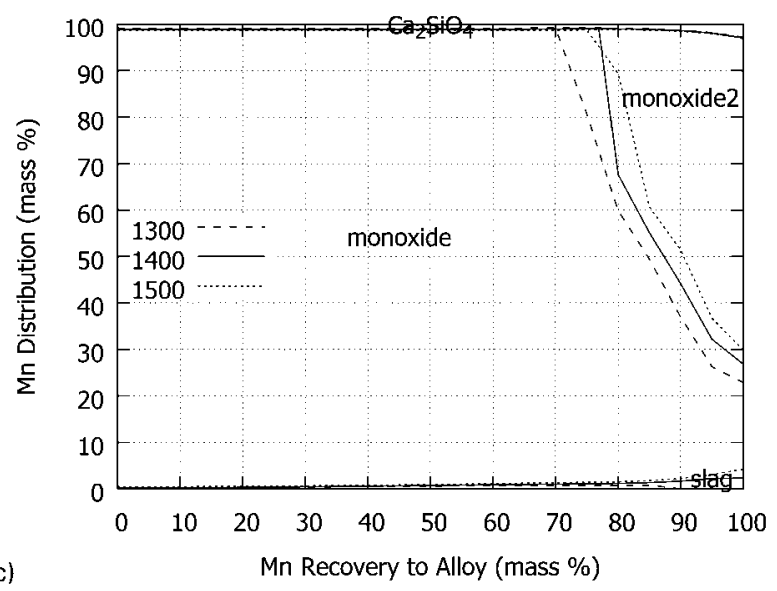

4 Ore manganese distribution across reduced ore phases. a: Ore1, b: Ore2, c: Ore3

consumed and the remainder of the $\mathrm{MnO}$ is contained in the slag. The Ore 2 residue forms $100 \%$ liquid slag at $1400^{\circ} \mathrm{C}$ for $80 \%$ manganese recovery. In contrast to Ore 1 and Ore2, Ore 3 contains only small quantities of slag over its entire reduction progression. The main phases present are monoxide and di-calcium silicate. With increased reduction the monoxide phase is consumed, resulting in the di-calcium silicate phase proportion increasing accordingly. In reduced Ore 3 the bulk of the manganese is contained in the monoxide phase at all levels of $\mathrm{MnO}$ reduction. In Ore3 at $70-80 \% \mathrm{MnO}$ recovery level, a second monoxide phase is formed in addition to the original monoxide phase. The difference in phase chemistry is that the second monoxide phase is enriched in $\mathrm{MgO}$ and the original monoxide is enriched in $\mathrm{CaO}$, but the $\mathrm{MnO}$ content is the same at each manganese recovery level.
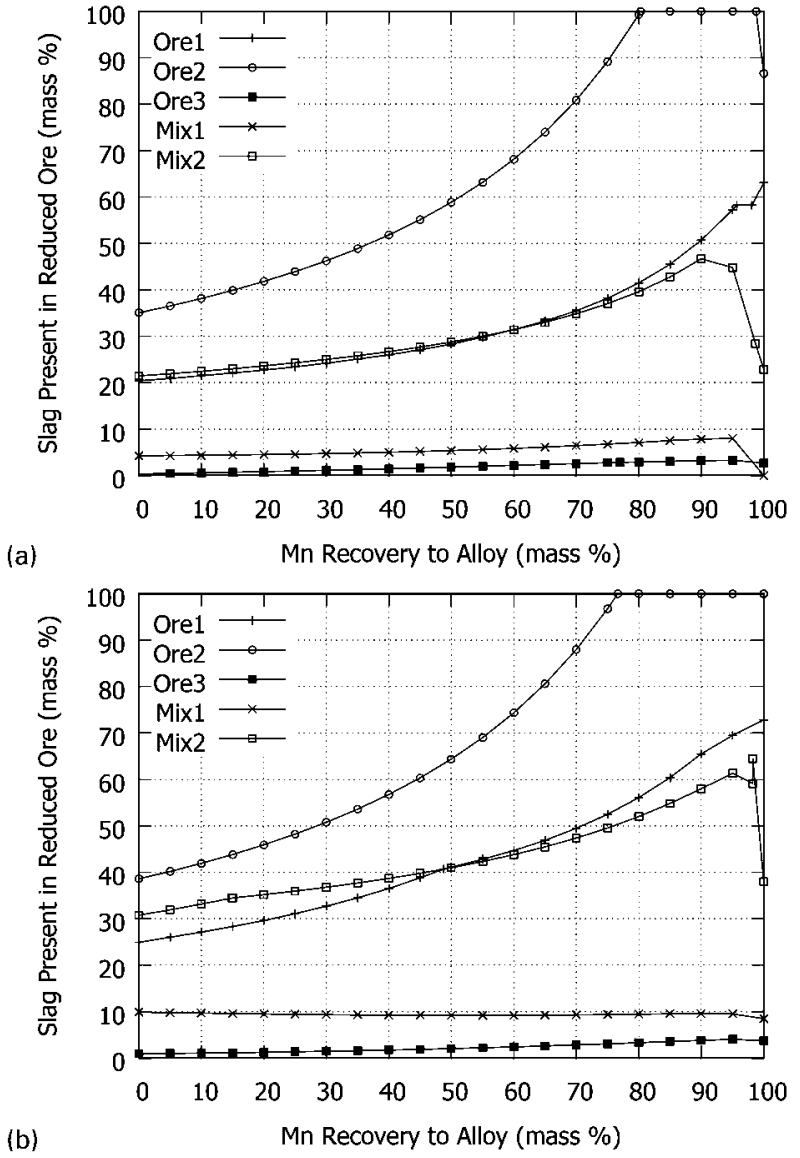
$5 \%$ Slag present in reduced ore $a$ at $1400^{\circ} \mathrm{C}, b$ at $1500^{\circ} \mathrm{C}$

From the previous work (summarised earlier) it is clear that the formation of liquid silicate hampers $\mathrm{MnO}$ reduction by acting as diffusion barriers that separate $\mathrm{MnO}$ from reductants, and also by lowering the activity of $\mathrm{MnO}$. Direct comparison of the calculated equilibrium proportions of liquid silicate in the three different ores and the two mixtures for 1400 and $1500^{\circ} \mathrm{C}$ is shown in Fig. $5 a$ and $b$. These temperatures were selected to be relevant to process conditions for the processing of ore fines. The two mixtures simulate ore mixtures required to produce an alloy of $75 \%$ manganese grade at approximately $80 \%$ manganese recovery to the alloy.

It is clear from comparison of the results in Fig. $5 a$ and $b$ that the proportion of liquid silicate phase formation is set by the ore chemical composition, with temperature having a limited influence (over this range): ore selection based on ore chemical composition is of prime importance in controlling the proportion of liquid silicate phase formed in the reduced ore. The importance of selecting the ore blending ratio to minimise slag formation is illustrated by the quite different slag phase proportions of Mix1 and Mix2 in Fig. $5 a$ and $b$.

In addition to the physical diffusion barrier formed by the liquid silicate phase in the reduced ore, if relatively more slag phase is present more $\mathrm{MnO}$ from the monoxide would dissolve in the slag phase resulting in decreased $\mathrm{MnO}$ activity in the reduced ore. The activity of $\mathrm{MnO}$ in the reduced ore particle is critical as it drives the overall carbothermic reduction reaction. It is well established that the $\mathrm{MnO}$ reduction rate remains high if $\mathrm{MnO}$ remains in the solid state as monoxide (Tangstad 


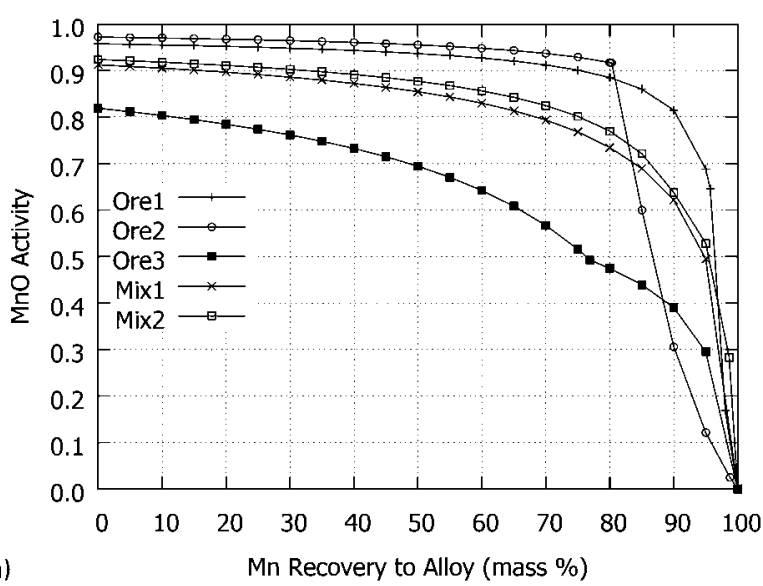

(a)

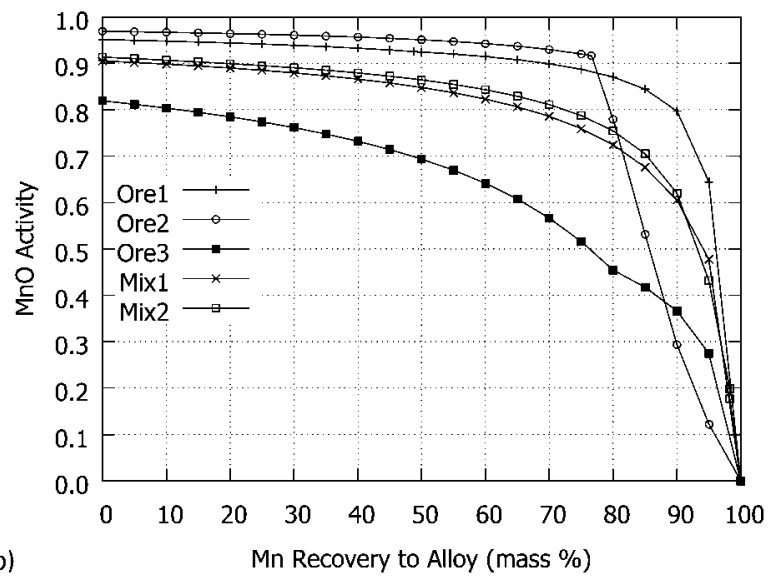

6 Activity of $\mathrm{MnO} a$ at $1400^{\circ} \mathrm{C}, \mathrm{b}$ at $1500^{\circ} \mathrm{C}$

and Olsen, 1997). The calculated activity of $\mathrm{MnO}$ in the system at 1400 and $1500^{\circ} \mathrm{C}$, using pure $\mathrm{MnO}$ as reference state, are shown in Fig. $6 a$ and $b$.

As would be expected, the $\mathrm{MnO}$ activity in Ore 3 is lowest because it contains less $\mathrm{MnO}$ than Orel and Ore2. A more instructive comparison is between Ore1 and Ore2: these two ores contain the same percentage of $\mathrm{MnO}$, so the effect of gangue oxides on the $\mathrm{MnO}$ activity is clearly illustrated. Ore1 and Ore2 have similar $\mathrm{MnO}$ activities down to $47 \% \mathrm{MnO}$ in the reduced ore $(80 \%$ manganese recovery) at $1400^{\circ} \mathrm{C}$, and $57 \% \mathrm{MnO}$ in the reduced ore $\left(76 \%\right.$ manganese recovery) at $1500^{\circ} \mathrm{C}$. These transition points correspond to the liquidus compositions for reduced Ore 2 at 1400 and $1500^{\circ} \mathrm{C}$; for larger extents of manganese reduction only slag is present in reduced Ore2. Upon further reduction the activity of $\mathrm{MnO}$ would drop precipitously. Based on previous work, it is expected that the reduction rate would slow correspondingly, as the chemical potential difference that drives the reduction reaction is drastically reduced.

Figure $6 a$ and $b$ shows that the mixtures (including Mix 2 containing $56 \%$ Ore 2 ) are predicted to maintain high $\mathrm{MnO}$ activities up to high degrees of reduction, similar to Ore1. Ore mixing would only be effective if the mixtures were homogeneous (as is the case for pellets). However, in the case of a loosely packed bed of ore fines and reductant homogenisation is not expected, and each ore particle would react according to its inherent chemistry. In such mixtures, recovery from Ore2 particles is expected to be limited as a result of excessive slag formation (resulting in decreased $\mathrm{MnO}$ activities and formation of diffusion barriers at the monoxide reaction interface). Should each ore react independently, it is expected that increasing the reaction temperature from $1400^{\circ} \mathrm{C}$ to $1500^{\circ} \mathrm{C}$ might not improve reduction kinetics, but might actually hamper the reduction reaction through increased slag formation.

Changing the temperature does also change the reaction equilibrium, but over the range considered here $\left(1400-1500^{\circ} \mathrm{C}\right)$ the change in reduction equilibrium is expected to be secondary in importance to the kinetic effect of slag formation, for the following reason. For the reduction reaction $\mathrm{MnO}+\mathrm{C}=\mathrm{Mn}+\mathrm{CO}$, assuming a carbon activity of 1 and $\mathrm{CO}$ partial pressure of $1 \mathrm{~atm}$, the equilibrium activity of $\mathrm{MnO}$ (solid reference state) is 0.35 at $1400^{\circ} \mathrm{C}$, and $0 \cdot 10$ at $1500^{\circ} \mathrm{C}$, based on a $\mathrm{Mn}$ activity of 0.3 (liquid reference state; calculated for carbon-saturated $75 \% \mathrm{Mn}$ ferromanganese using the unified interaction parameter model of $\mathrm{Li}$ and Morris, 1997). The conclusion is that, at both temperatures, the reduction reaction is well away from equilibrium if the system contains unreduced $\mathrm{MnO}$ with an activity close to 1 , and kinetic effects of temperature changes would be more important than changes in the reduction reaction equilibrium.

\section{Conclusion}

1. Previous work showed that the extent of slag formation determines the reduction rate and $\mathrm{MnO}$ recovery level that can be achieved in a furnace at a specific reaction temperature. Slag formation slows reduction by forming diffusion barriers at the monoxide reaction interface within the reduced ore.

2. FactSage thermochemical software can be used to calculate phase equilibria in manganese ore (including slag formation) to aid interpretation of differences in ore reduction behaviour.

3. Ore bulk chemical composition (total manganese and iron content) is likely to be a poor indicator of ore reducibility. Phase equilibria, and specifically slag formation, must be considered to predict the relative reduction rates of manganese ores.

4. Additions made to the ore to manipulate chemical composition to limit liquid silicate formation would be expected to be effective in reaction systems such as pellets in which close proximity of reactants promote homogenisation. This would not be the case in mixtures of fine ore and reductant in a packed bed; in such a mixture the ore would likely react according to its inherent chemical composition and not respond to additives.

5. An increase in temperature might not always remedy the problem of slow reaction rates. In some cases, the reduction rate might even decrease upon increasing temperature, due to excessive slagging.

\section{References}

Akdogan, G. and Eric, R. H. 1995. Kinetics of the solid-state carbothermic reduction of Wessel manganese ores, Metall. Mater. Trans. B, 26, 13-24.

Braga, R. S., Takano, C. and Mourao, M. B. 2007. Prereduction of selfreducing pellets of manganese ore, Ironmaking Steelmaking, 34, (4), 279-284.

Eric, R. H. and Burucu, E. 1992. The mechanism and kinetics of the carbothermic reduction of Mamatwan manganese ore fines, Miner. Eng., 5, (7), 795-815.

Fourie, L. J. 2000. Metal containing compound reduction and melting process, US Patent 6146437. 
Habashi, F. (ed.). 1997. Handbook of Extractive Metallurgy, Vol. 1, 420-437. Weinheim, Wiley-VCH

Kononov, R., Ostovski, O. and Ganguly, S. 2009. Carbothermic solid state reduction of manganese ores: 3 . Phase development, ISIJ Int., 49, (8), 1115-1122.

Koursaris, A., Kleynstuber, A. S. E. and Finn, C. W. P. 1983. A mineralogical investigation of the reduction of Mamatwan manganese ore with carbon, Spec. Publ. Geol. Soc. S. Afr., 7, 375-382.

Koursaris, A. and See, J. B. 1979. Discussion: reactions in the production of high-carbon ferromanganese from Mamatwan ore, J. S. Afr. Inst. Min. Metall., 79, 306-309.

Li, H. and Morris, A. 1997. Evaluation of unified interaction parameter model parameters for calculating activities for ferromanganese alloys: $\mathrm{Mn}-\mathrm{Fe}-\mathrm{C}, \mathrm{Mn}-\mathrm{Fe}-\mathrm{Si}, \mathrm{Mn}-\mathrm{C}-\mathrm{Si}$, and $\mathrm{Mn}-\mathrm{Fe}-\mathrm{C}-\mathrm{Si}$ systems, Metall. Mater. Trans. B, 28B, 553-562.

Miyauchi, Y., Mochida, M., and Fuchi, Y. 2001. High thermal electrical property of manganese ore production of high carbon ferromanganese, 236-243. Quebec City, INFACON IX.
Ostrovski, O., Anacleto, N. and Ganguly, S. 2004. Reduction of Manganese Ores by Methane-Containing Gas, 173-183. Cape Town, INFACON X.

Olsen, S. E., Tangstad, M. and Lindstad, T. 2007. Production of Manganese Ferroalloys, Trodheim, Tapir Academic Press.

Ostrovski, O. I. and Webb, T. J. M. 1995. Reduction of siliceous manganese ore by graphite, ISIJ Int., 35, (11), 13311339.

Peretyagin, V. A. and Pavlov, A. V. 2003. Aspects of the hightemperature reduction of manganese ores by coal, Metallurgist, 47, (9-10), 419-423.

Tangstad, M. and Olsen, S. E. 1997. Phase relations in ferromanganese slags during melting and reduction, in Proceedings of the 5th International Conference on Molten Slags, Fluxes and Salts, 549555, Sydney, ISS.

Van Deventer, J. S. J. 1987. The effect of gangue components on the reduction of manganosite by graphite: an isothermal kinetic study, Thermochim. Acta, 112, 365-377. 